\title{
Üniversite Öğrencilerinde Beden Kitle İndeksi, Tükenmişlik Düzeyi ve İyilik Hâli Arasındaki İlişskinin İncelenmesi
}

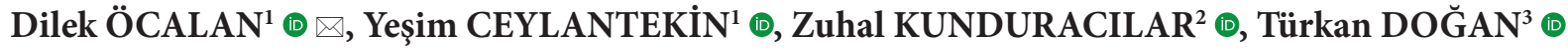 \\ ${ }^{1}$ Afyonkarahisar Sağlık Bilimleri Üniversitesi, Sağlık Bilimleri Fakültesi, Hemşirelik Bölümü, Afyonkarahisar, Türkiye \\ ${ }^{2}$ İstanbul Üniversitesi, Hamidiye Sağlik Bilimleri Fakültesi, Fizyoterapi ve Rehabilitasyon Bölümü, Kardiopulmoner Fizyoterapi ve \\ Rehabilitasyon Anabilim Dalı, İstanbul, Türkiye \\ ${ }^{3}$ Hacettepe Üniversitesi Eğitim Fakültesi, Rehberlik ve Psikolojik Danışmanlık Anabilim Dalı, Ankara, Türkiye \\ Bu çalışma, 27 Eylül - 28 Eylül 2019 tarihlerinde Zonguldak Bülent Ecevit Üniversitesi’nde düzenlenen “Endokrin Hastalıklara Multidisipliner Güncel Yaklaşım Kongresi; \\ IV. Zonguldak Endokrin Günleri” kapsamında sözel bildiri olarak sunulmuştur.
} Bu makaleye yapılacak atıf: Öcalan D, Ceylantekin Y, Kunduracılar Z, Doğan T. Üniversite Öğrencilerinde Beden Kitle İndeksi, Tükenmişlik Düzeyi ve İyilik Hâli Arasındaki İlişkinin
İncelenmesi. Türk Diyab Obez 2020;3: 270-278.

ÖZ

Amaç: Üniversite öğrencilerinin BKİ(Beden Kitle İndeksi)'lerinin iyilik hâli ve tükenmişlik düzeylerine etkisini belirlemek amaçlanmiştır.

Gereç ve Yöntemler: Toplam 953 üniversite öğrencisi ile gerçekleştirilen çalışmada "Kişisel Bilgi Formu”,"Maslach Tükenmişlik Envanteri- Öğrenci Formu" ve "İyilik Hâli Ölçeği"kullanılmıştır. Çalışma için gerekli etik izinler alınmıştır. Bu çalışmada elde edilen veriler SPSS 21 paket programı aracılı̆̆ı ile analiz edilmiştir.

Bulgular: Yaş ortalaması 20,86 $\pm 2,03$ yıl olan öğrencilerin, \%79,9’u BKİ $25 \mathrm{~kg} / \mathrm{m}^{23}$ nin altında normal kilolu, \%16,6'sı $25-30 \mathrm{~kg} / \mathrm{m}^{2}$ arasında fazla kilolu, \%3,6’s ise, $31 \mathrm{~kg} / \mathrm{m}^{2}$ ve üzeri olduğundan obezdir. Öğrencilerin \%53, $1^{\prime} \mathrm{inin}(\mathrm{n}=506)$ düzenli ve dengeli bir beslenme

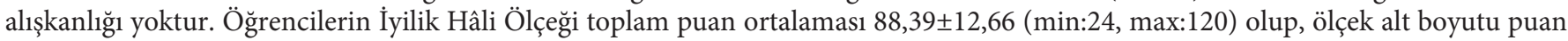
ortalamaları yaşamı anlamlandırma ve hedef odaklı olma $26,88 \pm 4,63$, bilişsel boyut $16,43 \pm 2,71$, duygusal alt boyut 17,65 $\pm 3,24$, fiziksel alt boyut 11,31 $\pm 3,33$, sosyal alt boyut 16,10 $\pm 2,60$ 'dır. Maslach Tükenmişlik Envanteri değerlendirildiğinde, öğrencilerin tükenme alt faktör

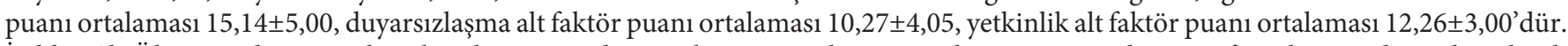
İyilik Hâli Ölçeği toplam puanları ile tükenme ve duyarsızlaşma puanları arasında $\% 35$ oranında negatif yönlü orta düzeyde anlamlı ilişki vardır (tükenme; $r=-0,359, p<0,001$, duyarsızlaşma; $r=-0,358, p<0,001$ ). İyilik Hâli Ölçeği toplam puanları ile yetkinlik puanları arasında ise, \%42 oranında pozitif yönlü orta düzeyde anlamlı ilişki vardır $(r=0,428, p<0,001)$. Ögrencilerin BKİ puanları ile tükenmişlik puanları arasında anlamlı ilişki yoktur $(\mathrm{p}=0,189)$. Öğrencilerin BKİ ile İyilik hâli ölçek puanları arasında pozitif yönlü düşük düzeyde anlamlı ilişki vardır $(\mathrm{r}=0,273, \mathrm{p}<0,024)$.

Sonuç: Öğrencilerin düzenli ve dengeli bir beslenme alışkanlıklarının olmaması, gelecekte preobez ve obez popülasyonunun artması açısından oldukça önemli bir risktir. Öğrencilerin iyilik hâli düzeyi arttıkça yetkinlik durumları artmakta, tükenme ve duyarsızlaşma durumları azalmaktadır. Öğrencilerin BKİ’leri tükenmişlik durumlarını değiştirmezken, iyilik hâli durumlarını olumlu etkilemektedir.

Anahtar Sözcükler: Beden kitle indeksi, Tükenmişlik, L̇yilik hâli

\section{An Examination of the Relationship Among University Students' Body Mass Index (BMI), Burnout Level and Wellness}

\begin{abstract}
Aim: To examine the impact of body mass index (BMI) of university students on burnout levels and wellness.

Material and Methods: In the study, 953 university students were enrolled. 'Personal Information Form', 'Maslach Burnout InventoryStudent Survey' and 'Wellness Scale' were the instruments of the study. Ethical approvals were received for the study. In this study, the data were analyzed using the SPSS 21 package program.
\end{abstract}

ORCID: Dilek Öcalan / 0000-0001-8986-6449, Yeşim Ceylantekin / 0000-0003-3410-9496, Zuhal Kunduracilar / 0000-0002-1351-2967, Türkan Doğan / 0000-0002-5976-7666 
Results: Of all participants, \%74.6 were female and \%25.4 were male. Their mean age was $20.86 \pm 2.03$. \%32.5 were physiotherapy students, \%30.7 were nursing students, $\% 26.3$ were health institutions management students and \%10.4 were nutrition and dietetics students. \%51.1 $(\mathrm{n}=506)$ of the students do not have a regular and balanced diet. As for the BMI of participants, \%79.9 were labelled as normal weight with the value under $25 \mathrm{~kg} / \mathrm{m}^{2}, \% 16.6$ were overweight with $25-30 \mathrm{~kg} / \mathrm{m}^{2}$ and \%3.6 were found to be obese with $31 \mathrm{~kg} /$ $\mathrm{m}^{2}$. The mean wellness scores of the participants were $88.39 \pm 12.66$ ( $\min : 24$, max:120). As for the subscales, the mean scores of giving meaning to life and being goal- driven were $26.88 \pm 4.63$; of cognitive subscale was $16.43 \pm 2.71$; of emotional subscale was $17.65 \pm 3.24$; of

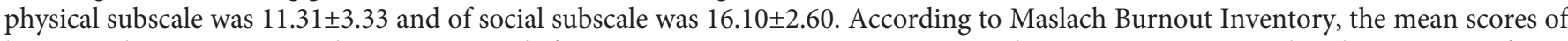
burnout, desensitization and competence sub-factors were $15.14 \pm 5.00,10.27 \pm 4.05$ and $12.26 \pm 3.00$, respectively. There is a significant moderate and negative oriented relationship (\%35) among students' total scores of Wellness Scale, burnout and desensitization scores (burnout; $\mathrm{r}=-0.359$; desensitization $\mathrm{r}=-0.358 ; \mathrm{p}<0.001$ ). However, there is a significant moderate and positive oriented relationship (\%42) between their total scores of Wellness Scale and competence scores $(\mathrm{r}=0.428, \mathrm{p}<0.001)$. There is no significant relationship between BMI of the students and burnout score $(\mathrm{p}=0.189)$. Nevertheless, there is a significant low and positive oriented relationship between BMI of the students and Wellness Scale scores $(\mathrm{r}=0.273, \mathrm{p}<0.024)$.

Conclusion: The fact that students do not have a regular and balanced diets dies poses a risk of increase in the population of pre-obese and obese in the future. The more students' level of wellness increases, the more their level of competence increases while the burnout and desensitization levels decrease. BMI of the students has been found to have a positive impact upon students' wellness although it has no effect on burnout level.

Key Words: Body mass index, Burnout, Wellness

\section{GíRIȘ}

Beslenme yaşamın her döneminde sağlığın temelini oluşturur. Erken yaşlarda kazandırılan sağlıklı beslenme alışkanlıkları ve davranışları ilerleyen dönemlerde besin çeşitliliğine göre besin seçiminde, yaşam kalitesinin yükseltilmesinde ve sağlığın korunmasında önemli bir belirleyicidir (1).

Yeterli ve dengeli beslenme alışkanlıklarına ilişkin diyette yapılan değişiklikler bireylerin sağlık durumunun korunmasını sağlarken, gelecekte ortaya çıkabilecek kanser, kardiyovasküler hastalıklar, diyabet, hipertansiyon, osteoporoz vb. hastalıkların oluşum riskini de önlemektedir (1).

Ergenlik ve gençlik dönemi, beslenme davranışları açısından oldukça risklidir. Bu dönemde aileden bağımsız yemek yeme alışkanlığ 1 ile birlikte yiyecek tercihleri değişir. Özellikle yağ ve kalori bakımından zengin, fast-food beslenme sıklığındaki artış ve fiziksel aktivitedeki azalma, obezite ve yeme bozuklukları oranlarının artmasına neden olabilmektedir $(2,3)$.

Dünya Sağlık Örgütü (DSÖ) obeziteyi, sağlığı bozacak ölçüde vücutta aşırı yağ birikmesi olarak tanımlanmaktadır. Günlük alınan enerjinin tüketilen enerjiden fazla olması durumunda, sarf edilemeyen enerji vücutta yağ olarak depolanmakta ve bu yağ birikintileri obeziteye neden olmaktadır. Kilo aşamaları beden kitle indeksi BKİ ile tanımlanır(4). BKİ; $\leq 18,5$ zayıf, 18,5 - 24,9 normal kilo, 25 - 29,9 pre-obez, 30 - 34,9, birinci derece obez, ve $\geq 35$ ikinci derece ya da ağır obez (morbid-ölümcül) olarak değerlendirilmektedir (5).

Global bir sağlık problemi hâline gelen obezitenin sebep olduğu hastalık ve ölümlerin giderek artacağı öngörülmektedir $(6,7)$. Obeziteye en fazla zemin hazırlayan faktörler; sağlıksız ve aşırı beslenme ile fiziksel aktivite eksikliğidir. Ayrıca nörolojik, fizyolojik, genetik, çevresel, kültürel ve psikolojik etmenlerin de obeziteye yol açtığ $(8,9,10)$.

Çok boyutlu bir kavram olarak ele alınan sağlık "sadece fiziksel güçsüzlügün veya hastalıkların olmaması değil, fiziksel, ruhsal ve sosyal olarak tam bir iyilik hâli” olarak tanımlanmıştır $(11,12)$. Diğer bir ifade ile sağlık sadece hastalığın olmayışı değil, bunun ötesinde "iyi olma hâli" olarak tanımlanmaktadır. Literatürde, genel olarak iyilik hâli kavramı "bireyin bedensel, zihinsel ve ruhsal bütün boyutlarda işlerliğinin geliştirilmesinin amaçlandığı bir yaşam biçimi” olarak tanımlanır $(13,14,15)$. Tanımın en dikkat çekici noktalarından biri iyilik hâlinin yaşam biçimi olarak tanımlanmasıdır. Ergenlik ve genç yetişkinlik dönemi ise yaşam biçiminde değişiklikler yapma açısından son derece önemlidir.

Tükenmişlik terimi ise, literatürde "kişinin psikolojik olarak tükenmesine yol açan fiziksel kaynakların boşaltılması" olarak tanımlanır. Diğer bir ifadeyle tükenmişlik, duygusal olarak zorlayıcı olan durumlara uzun süre maruz kalmaktan kaynaklanan bedensel, duygusal ve mental bir bitkinlik hâlidir $(16,17)$. Toplumda giderek yaygınlaşan tükenmişlik tablosunun neden ve nasıl oluştuğu, nasıl başa çıkılabileceği ve korunma yolları hem araştırmacılar hem de klinisyenler tarafindan önemle üzerinde durulan bir sorundur $(18,19)$.

Günümüzde özellikle genç popülasyonda sağlıklı yaşam biçimi davranışlarının geliştirilmesi ve sürdürülmesi, BKİ (Beden Kitle İndeksi)'lerinin normal sınırlarda olması oldukça önemlidir. Fiziksel, ruhsal ve sosyal olarak sağlıklı olan, kendini iyi ve sağlıklı hisseden bireylerin tükenmişlik 
yaşaması oldukça güçtür. Yukarıdaki satırlarda da vurgulandığı üzere ergenlik ve genç yetişkinlik dönemi sağlıksız yaşam biçiminin sağlıklı yaşam biçimi ile değiştirilmesi açısından önemli ve kritik bir dönemdir. Gençlere sağlıklı yaşam biçimi seçenekleri sunulmadan önce mevcut durumun saptanması gereklidir. Bu düşünceden hareketle bu çalışmanın amacı üniversite öğrencilerinin BKİ’lerinin iyilik hâli ve tükenmişlik düzeylerine etkisini değerlendirmektir.

\section{GEREÇ ve YÖNTEMLER}

Tanımlayıcı ve kesitsel tipte olan araştırmanın evrenini, Afyonkarahisar Sağlık Bilimleri Üniversitesi Sağlık Bilimleri Fakültesi'ne kayıtlı 1868 öğrenci oluşturmuştur. Evren büyüklüğü 1868 olan araştırmada örneklem seçimine gidilmeden evrenin tamamına ulaşılması planlanmıştır. Veri toplama sürecinde araştırmaya katılmaya gönüllü olan, araştırma kriterlerine uygun olan 953 öğrenci ile çalışma yürütülerek kayıtlı tüm öğrencilerin \%51'ine ulaşılmıştır. Araştırmaya dahil olma kriterleri; Afyonkarahisar Sağllk Bilimleri Üniversitesi Sağlık Bilimleri Fakültesi’ne kayıtlı öğrenci olmak, DM tanısı almış olmamak, herhangi bir kronik hastalığı (Hipertansiyon, Kardiyolojik, nörolojik ve ortopedik hast.) olmamak, herhangi bir ilaç kullanmamak ve çalışmaya katılmaya gönüllü olmaktır. Bu çalışma için, Afyonkarahisar Sağlık Bilimleri Üniversitesi Tibbi Etik Kurulu'nun 04.10.2019 tarihinde, 2011-KAEK2 kodlu, 2019/334 sayılı kararı ile etik onay alınmıştır. Çalışmada“Maslach Tükenmişlik Envanteri- Öğrenci Formu (MTEÖF)" (20, 21), "İyilik Hâli Yıldız Ölçeği”(22) ve araştırmacılar tarafından hazırlanan "Kişisel Bilgi Formu" kullanılarak yüzyüze görüşme tekniği uygulanmıştır. Antropometrik ölçüm yapılarak, her katılımcının BKİ hesaplanmıştır.

Maslach Tükenmişlik Envanteri-Öğrenci Formu (MTEÖF): Çalışmada, Schaufeli ve ark. tarafından geliştirilen ve Türkçe uyarlaması Çapri ve ark. tarafından yapılan Maslach Tükenmişlik Envanteri-Öğrenci Formu (MTE-ÖF) kullanılmıştır $(20,21)$. Çapri ve ark. MTÖ-ÖF’nun üniversite öğrencileri örnekleminde uyarlama, geçerlik ve güvenirlik çalışmalarını gerçekleştirdikleri araştırmalarında, ölçeğin orijinaline uygun üç alt faktörlü bir yapıya ulaştıklarını, 16 maddelik ölçeğin 13 maddeye indirildiğini rapor etmişlerdir. Ölçeğin yapı geçerliği için yapılan doğrulayıcı faktör analizi sonucunda, 13 maddeden oluşan 3 faktörlü bir yapı elde edilmiştir. Bu alt faktörler "tükenme (5 madde)", "duyarsizlaşma (4 madde)" ve "yetkinlik (4 madde)" olarak isimlendirilmişlerdir (21). Ölçekten elde edilen alt faktörlere ait puanlar arasındaki korelasyonların 0,32 ile 0,83 arasında değiştiği görülmüştür. Madde geçerliğine kanıt olarak madde toplam test korelasyonları hesaplanmış ve alt faktörlerin korelasyon değerlerinin 0,32 ile 0,69 arasında değiştiği saptanmıştır. Uygulamada, MTÖ-ÖF’nin alt ölçekleri ayrı ayrı puanlanmakta ve değerlendirilmektedirler. "Tükenme" ve "duyarsızlaşma" alt faktörlerinde alınan yüksek puanlar; diğer taraftan, "yetkinlik" alt faktöründe alınan düşük puanlar tükenmişliğin olduğunu göstermektedir $(20,21)$. Türkçe uyarlama çalışmasında 5'li derecelendirme (hiçbir zaman, bazen, genellikle, çoğu zaman, her zaman) biçimi benimsenmiştir. Tükenme (T): 1, 4, 7, 10 ve 13 . maddeler, Duyarsızlaşma (DY): 2, 5, 8 ve 11. maddeler ve Yetkinlik (Y): 3, 9, 14 ve 16. Maddeler olarak tanımlanır. Tükenme ve duyarsızlaşma alt ölçeklerindeki yüksek puan, yetkinlik (ters puanlanmaktadır) alt ölçeğindeki düşük puan tükenmişliği göstermektedir. Puanlamada, her bir kişi için üç ayrı tükenmişlik puanı hesaplanmaktadır (21).

Íyilik Hâli Yıldızı Ölçeği: Korkut-Owen ve ark. tarafından Türkiye'ye özgü bir iyilik hâli modeli geliştirme çalışmaları yapılmış ve İyilik Hâli Yıldızı Ölçeği'nin geliştirilmiştir. Toplam 24 maddeden oluşan ölçeğin beş alt boyutu bulunmaktadır. Bunlar; Yaşamı anlamlandırma ve hedef odaklı olma (7 madde), Bilişsel Boyut (4 madde), Duygusal Boyut (5 madde), Fiziksel Boyut (4 madde) ve Sosyal Boyuttur (4 madde). Beşli Likert tipi ölçek yapısında "beni hiç yansıtmiyor" (1puan). "beni yansitmiyor"(2 puan); "bazen" (3 puan), "beni yansitiyor" (4 puan), "tamamen beni yansit1yor" (5 puan) olarak değerlendirilir. Toplam ölçekten elde edilen minimum puan 24 , maksimum puan 120 'dir. İç tutarlılık katsayısı hesaplamasında ölçeğin toplamı için $r=$ $0,84(\mathrm{p}<.01)$, yaşamı anlamlandırma ve hedef odaklı olma, bilişsel, duygusal, fiziksel ve sosyal alt boyutları için sırasıyla 0,$83 ; 0,72,0,60,0,57$ ve 0,65 olarak hesaplanmıştır (22).

$\mathrm{Bu}$ çalışmada elde edilen veriler SPSS 21 paket programı aracılığı ile analiz edilmiştir. Her bir karşılaştırma için verilerin normallik testleri Kolmogorov-Smirnov testi ile yapılmıştır. Verilerin normal dağılmaması nedeni ile, iki gruplu karşılaştırmalarda Mann-Whitney U testi, üç ve daha fazla gruplu karşılaştırmalarda ise Kruskall-Wallis $\mathrm{H}$ testi kullanılmıştır. Değişkenler arasındaki ilişkiye Spearman's rho testi ile bakılmıştır. Anlamlılık seviyesi olarak 0,05 kullanılmış olup, $p<0,05$ olması durumunda anlamlı farklıllı̆ın/ilişkinin olduğu, $p>0,05$ olması durumunda ise anlamlı farkl1lığın/ilişkinin olmadığı belirtilmiştir.

\section{BULGULAR}

Katılımcıların yaş ortalamaları 20,86 $\pm 2,03$ yıl olup, $\% 74,6$ 's $(\mathrm{n}=711)$ kadın, \%25,4'ü $(\mathrm{n}=242)$ erkektir. Öğrencilerin \%32,5’i ( $n=310)$ fizyoterapi bölümü, \%30,7'si hemşirelik bölümü ( $\mathrm{n}=293), \% 26,3$ ( $\mathrm{n}=251)$ sağlık kurumları yöneticiliği bölümü, \%10,4 $(\mathrm{n}=99)$ beslenme ve diyetetik bölümünde okumaktadır. Çalışmaya katılan öğrencilerin genel not ortalamas1 2,65 $\pm 0,41(\min =1,00, \max =4,00)$ 'dir (Tablo 
1). Öğrencilerin \%83,7'sinin ekonomik durumu orta düzeyde olup, \%52'9'u devlet yurdunda kalmakta, \%73,2'si sigara, \%83,9'u alkol kullanmamaktadır. Çalışmada sorulan "Düzenli ve dengeli bir beslenme alışkanlığınız var mı?"

Tablo 1: Öğrencilerin bazı sosyodemografik özellikleri.

\begin{tabular}{|c|c|c|}
\hline \multicolumn{3}{|l|}{ Sosyodemografik Özellikler } \\
\hline Yaş Ortalaması & \multicolumn{2}{|c|}{$20,86 \pm 2,03(\mathrm{SD})$} \\
\hline Min-max. & \multicolumn{2}{|c|}{$17-36$} \\
\hline Genel Not Ortalaması & \multicolumn{2}{|c|}{$2,65 \pm 0,41(\mathrm{SD})$} \\
\hline Min-Max & \multicolumn{2}{|c|}{$1-4$} \\
\hline Bölüm & Sayı & $\%$ \\
\hline Hemşirelik & 293 & 30,7 \\
\hline Beslenme & 99 & 10,4 \\
\hline Sağlık Kurumları Yöneticiliği & 251 & 26,3 \\
\hline Fizyoterapi & 310 & 32,5 \\
\hline \multicolumn{3}{|l|}{ Cinsiyet } \\
\hline Kadın & 711 & 74,6 \\
\hline Erkek & 242 & 25,4 \\
\hline \multicolumn{3}{|l|}{ Sinif } \\
\hline 1. sinif & 315 & 33,1 \\
\hline 2. sinif & 208 & 21,8 \\
\hline 3. sinif & 222 & 23,3 \\
\hline 4. $\sin 1 f$ & 208 & 21,8 \\
\hline \multicolumn{3}{|l|}{ Ekonomik durum } \\
\hline Çok iyi & 54 & 5,7 \\
\hline Orta & 798 & 83,7 \\
\hline Kötü & 81 & 8,5 \\
\hline Çok iyi & 20 & 2,1 \\
\hline \multicolumn{3}{|l|}{ Yaşadığı Yer } \\
\hline Devlet yurdu & 504 & 52,9 \\
\hline Arkadaş ile evde & 99 & 10,4 \\
\hline Özel yurt & 139 & 14,6 \\
\hline Yalnız evde & 150 & 15,7 \\
\hline Aile ile evde & 61 & 6,4 \\
\hline Toplam & 953 & 100 \\
\hline
\end{tabular}

sorusuna öğrencilerin \%53,2'sinin ( $\mathrm{n}=507)$ "hayır" cevabını verdiği belirlenmiştir. Katılımcıların BKİ incelendiğinde; \%79,9’u ( $\mathrm{n}=760)$ BKİ $25 \mathrm{~kg} / \mathrm{m}^{2}$ nin altında normal kilolu, \%16,6'sı ( $\mathrm{n}=158) 25-30 \mathrm{~kg} / \mathrm{m}^{2}$ arasinda fazla kilolu ve $\% 3,6$ 's1 ( $\mathrm{n}=34) 31 \mathrm{~kg} / \mathrm{m}^{2}$ ve üzeri olduğundan obezdir. Çalışmada, öğrencilerin düzenli ve dengeli bir beslenme alışkanlıkları olup olmama durumları ile BKİ arasında anlamlı bir fark bulunmamıştır $(p=0,162)$. Cinsiyet değişkeni açısından ise, erkek öğrencilerin BKİ ortalamaları $(23,74 \pm 3,46)$, kız öğrencilerin BKİ ortalamalarından $(21,78 \pm 6,66)$ anlamlı derecede yüksektir $(\mathrm{p}<0,001)$ (Tablo 2). Öğrencilerin öğrenim durumları, aile tipleri, sosyal güvence durumları ile alkol kullanma durumları arasında BKİ değerleri açısından anlamlı bir farklılık görülmemiştir (sırasıyla $\mathrm{p}=0,603$; $\mathrm{p}=0,416 ; \mathrm{p}=0,998 ; \mathrm{p}=0,994) \quad$ (Tablo 3). Öğrencilerin okudukları bölüm, sınıf, sosyo-ekonomik durum ve sigara içme durumları ile BKİ değerleri arasında anlamlı farkl1lık görülmemektedir (sırasılyla $\mathrm{p}=0,072 ; \mathrm{p}=0,860 ; \mathrm{p}=0,691$; $\mathrm{p}=0,225)$. Ancak yaşanılan yerlere göre BKİ anlamlı derecede farklılık görülmektedir. Yalnız evde yaşayanlarda BKİ değerleri devlet yurdunda kalanlara göre anlamlı derecede yüksek görülmektedir ( $\mathrm{p}=0,013)$ (Tablo 4).

Öğrencilerin İyilik Hâli Yıldızı Ölçeği toplam puan ortalaması 88,39 $\pm 12,66$ olup, ölçek alt boyutu puan ortalamaları yaşamı anlamlandırma ve hedef odaklı olma $26,88 \pm 4,63$, bilişsel boyut $16,43 \pm 2,71$, duygusal alt boyut $17,65 \pm 3,24$, fiziksel alt boyut $11,31 \pm 3,33$, sosyal alt boyut $16,10 \pm 2,60$ 'dır. Maslach Tükenmişlik Envanteri- Öğrenci Formu (MTEÖF) değerlendirildiğinde öğrencilerin tükenme alt faktör puanı ortalaması $15,14 \pm 5,00$, duyarsızlaşma alt faktör puanı ortalaması $10,27 \pm 4,05$, yetkinlik alt faktör puanı ortalaması $12,26 \pm 3,00$ 'dür. Bölümler arasında duyarsızlaşma puanları açısından anlamlı fark vardır. Beslenme bölümüne okuyan

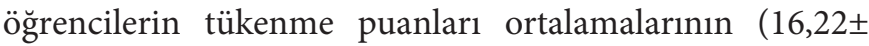
$4,86)$ sağlık kurumları yöneticiliği bölümünde okuyanlara göre $(14,58 \pm 5,03)$ anlamlı derecede yüksek olduğu belirlenmiştir ( $\mathrm{p}=0,026)$. Hemşirelik bölümündeki öğrencilerin ise, duyarsızlaşma puanları ortalamalarının $(9,72 \pm 4,04)$, beslenme bölümü $(11,71 \pm 4,16)$ ve sağlik kurumları yöneticiliği bölümüne $(10,68 \pm 4,14)$ göre anlamlı derecede düşük olduğu belirlenmiştir $(\mathrm{p}<0,001)$.

Tablo 2: Cinsiyet değişkenine göre öğrencilerin BKİ ortalamalarının karşılaştırılması.

\begin{tabular}{lclc}
\hline \multirow{2}{*}{ Cinsiyet } & & BKI & Mann-Whitney U testi \\
\cline { 2 - 3 } & $\mathbf{N}$ & Median (min-max) & P \\
\hline Erkek & 242 & $23,59(17,53-36,23)$ & \\
\hline Kadın & 711 & $21,01(15,79-175,21)$ & $<\mathbf{0 0 0 1}$ \\
\hline Toplam & 953 & $21,50(15,79-175,21)$ & \\
\hline
\end{tabular}


Tablo 3: Öğrencilerin öğrenim türü, aile tipi, sosyal güvence ve alkol kullanma durumları ile BKİ karşılaştırması.

\begin{tabular}{|c|c|c|c|c|}
\hline \multirow{2}{*}{\multicolumn{2}{|c|}{ Bazı Demografik Özellikler }} & \multicolumn{2}{|r|}{ BKİ } & \multirow{2}{*}{$\begin{array}{c}\text { Mann-Whitney U testi } \\
\text { P }\end{array}$} \\
\hline & & $\mathbf{n}$ & Median (min-max) & \\
\hline \multirow{3}{*}{ Öğrenim türü } & Normal & 738 & $21,49(15,79-36,23)$ & \multirow{3}{*}{0,603} \\
\hline & İkinci & 215 & $21,64(16,22-175,21)$ & \\
\hline & Toplam & 953 & $21,50(15,79-175,21)$ & \\
\hline \multirow{3}{*}{ Aile tipi } & Çekirdek & 792 & $21,56(15,81-175,21)$ & \multirow{3}{*}{0,416} \\
\hline & geniş aile & 161 & $21,19(15,79-35,70)$ & \\
\hline & Toplam & 953 & $21,50(15,79-175,21)$ & \\
\hline \multirow{3}{*}{$\begin{array}{l}\text { Sosyal } \\
\text { güvence }\end{array}$} & Var & 777 & $21,50(15,79-175,21)$ & \multirow{3}{*}{0,998} \\
\hline & Yok & 176 & $21,46(16,22-32,81)$ & \\
\hline & Toplam & 953 & $21,50(15,79-175,21)$ & \\
\hline \multirow{3}{*}{$\begin{array}{l}\text { Alkol } \\
\text { kullanma } \\
\text { durumu }\end{array}$} & Kullaniyor & 153 & $21,50(15,81-32,81)$ & \multirow{3}{*}{0,994} \\
\hline & Kullanmiyor & 800 & $21,50(15,79-175,21)$ & \\
\hline & Toplam & 953 & $21,50(15,79-175,21)$ & \\
\hline
\end{tabular}

Tablo 4: Öğrencilerin bölüm, sınıf, sosyoekonomik durum, yaşanılan yer ve sigara içme durumları ile BKİ karşılaştırması.

\begin{tabular}{|c|c|c|c|c|c|}
\hline \multirow{2}{*}{\multicolumn{2}{|c|}{ Bazı Demografik Özellikler }} & \multicolumn{2}{|r|}{ BKI } & \multicolumn{2}{|c|}{ Kruskall-Wallis $\mathrm{H}$ testi } \\
\hline & & $\mathbf{n}$ & Median (min-max) & $\mathbf{P}$ & İkili karşılaştırma \\
\hline \multirow{5}{*}{ Bölüm } & Beslenme & 99 & $20,82(15,82-30,08)$ & \multirow{5}{*}{0,072} & \multirow{5}{*}{-} \\
\hline & Hemşirelik & 293 & $21,55(16,65-36,23)$ & & \\
\hline & Fizyoterapi & 310 & $21,63(15,81-35,70)$ & & \\
\hline & Sky & 251 & $21,46(15,79-175,21)$ & & \\
\hline & Toplam & 953 & $21,50(15,79-175,21)$ & & \\
\hline \multirow{5}{*}{ Sinif } & 1. Sinif & 315 & $21,51(16,26-36,23)$ & \multirow{5}{*}{0,860} & \multirow{5}{*}{-} \\
\hline & 2. Sinif & 208 & $21,64(16,30-175,21)$ & & \\
\hline & 3. Sinif & 222 & $21,37(15,81-32,47)$ & & \\
\hline & 4. Sinif & 208 & $21,58(15,79-35,16)$ & & \\
\hline & Toplam & 953 & $21,50(15,79-175,21)$ & & \\
\hline \multirow{5}{*}{$\begin{array}{c}\text { Sosyo-Ekonomik } \\
\text { Durum }\end{array}$} & Çok iyi & 54 & $21,88(16,33-32,74)$ & \multirow{5}{*}{0,691} & \multirow{5}{*}{-} \\
\hline & Orta & 798 & $21,48(15,79-175,21)$ & & \\
\hline & Kötü & 81 & $21,72(16,02-36,23)$ & & \\
\hline & Çok kötü & 20 & $21,55(17,24-32,65)$ & & \\
\hline & Toplam & 953 & $21,50(15,79-175,21)$ & & \\
\hline \multirow{6}{*}{ Yaşanılan yer } & Devlet yurdu & 504 & $21,23(15,81-36,23)$ & \multirow{6}{*}{0,013} & \multirow{6}{*}{$\begin{array}{c}\text { Devlet yurdu-yalnız } \\
\text { evde yaşayanlar }\end{array}$} \\
\hline & Arkadaş ile evde & 99 & $21,74(17,31-32,47)$ & & \\
\hline & Özel yurt & 139 & $21,80(15,82-32,28)$ & & \\
\hline & Yalnız evde & 150 & $22,18(15,79-175,21)$ & & \\
\hline & Aile ile evde & 61 & $21,91(17,15-35,16)$ & & \\
\hline & Toplam & 953 & $21,50(15,79-175,21)$ & & \\
\hline \multirow{4}{*}{$\begin{array}{l}\text { Sigara içme } \\
\text { durumu }\end{array}$} & İçiyorum & 226 & $22,05(15,81-175,21)$ & \multirow{4}{*}{0,225} & \multirow{4}{*}{ - } \\
\hline & İçmiyorum & 698 & $21,45(15,79-36,23)$ & & \\
\hline & Biraktım & 29 & $21,60(16,30-30,30)$ & & \\
\hline & Toplam & 953 & $21,50(15,79-175,21)$ & & \\
\hline
\end{tabular}


Tablo 5: Öğrencilerin iyilik hâli yıldız ölçeği ve maslach tükenmişlik envanteri-öğrenci formu (MTE-ÖF) puan ortalamaları arasındaki ilişki.

\begin{tabular}{|c|c|c|c|c|c|c|c|}
\hline \multicolumn{2}{|c|}{ Ölçek Alt Boyutları } & $\begin{array}{c}\text { (İHÖ) } \\
\text { Yaşamın anlamı }\end{array}$ & $\begin{array}{l}\text { (İHÖ) } \\
\text { Bilişsel }\end{array}$ & $\begin{array}{c}\text { (İHÖ) } \\
\text { Duygusal }\end{array}$ & $\begin{array}{c}\text { (İHÖ) } \\
\text { Fiziksel }\end{array}$ & $\begin{array}{l}\text { (IHÖ) } \\
\text { Sosyal }\end{array}$ & $\begin{array}{c}\text { İyilik Hâli Ölçeği } \\
\text { Toplam Puan }\end{array}$ \\
\hline \multirow{3}{*}{$\begin{array}{l}\text { (MTE-ÖF) } \\
\text { Tükenme }\end{array}$} & $\mathrm{r}^{*}$ & $-0,303$ & $-0,265$ & $-0,288$ & $-0,268$ & $-0,185$ & $-0,359$ \\
\hline & $\mathrm{p}$ & $<0,001$ & $<0,001$ & $<0,001$ & $<0,001$ & $<0,001$ & $<0,001$ \\
\hline & $\mathrm{N}$ & 953 & 953 & 953 & 953 & 953 & 953 \\
\hline \multirow{3}{*}{$\begin{array}{l}\text { (MTE-ÖF) } \\
\text { Duyarsızlaşma }\end{array}$} & $\mathrm{r}^{*}$ & $-0,310$ & $-0,286$ & $-0,251$ & $-0,218$ & $-0,267$ & $-0,358$ \\
\hline & $\mathrm{p}$ & $<0,001$ & $<0,001$ & $<0,001$ & $<0,001$ & $<0,001$ & $<0,001$ \\
\hline & $\mathrm{N}$ & 953 & 953 & 953 & 953 & 953 & 953 \\
\hline \multirow{3}{*}{$\begin{array}{l}\text { (MTE-ÖF) } \\
\text { Yetkinlik }\end{array}$} & $\mathrm{r}^{*}$ & 0,386 & 0,322 & 0,356 & 0,256 & 0,244 & 0,428 \\
\hline & $\mathrm{p}$ & $<0,001$ & $<0,001$ & $<0,001$ & $<0,001$ & $<0,001$ & $<0,001$ \\
\hline & $\mathrm{N}$ & 953 & 953 & 953 & 953 & 953 & 953 \\
\hline
\end{tabular}

$\mathbf{r}=$ Spearman's rho testi

Bölümler arasında iyilik hâli ölçeği puan ortalamaları açısından anlamlı fark vardır. Hemşirelik bölümü öğrencilerinin iyilik hâli düzeyi fizyoterapi öğrencilerine göre daha yüksektir $(\mathrm{p}=0,017)$.

Öğrencilerin İyilik Hâli Yıldız Ölçeği toplam puanları ile tükenme ve duyarsızlaşma puanları arasında \%35 oranında negatif yönlü orta düzeyde anlamlı ilişki vardır (tükenme; $\mathrm{r}=-0,359, \quad \mathrm{p}<0,001$, duyarsızlaşma; $\mathrm{r}=-0,358, \mathrm{p}<0,001)$. Öğrencilerin İyilik Hâli Yıldız Ölçeği toplam puanları ile yetkinlik puanları arasında ise, $\% 42$ oranında pozitif yönlü orta düzeyde anlamlı ilişki vardır $(\mathrm{r}=0,428, \mathrm{p}<0,001)$ (Tablo $5)$.

Öğrencilerin BKİ puanları ile tükenmişlik puanları arasında anlamlı ilişki yoktur. Öğrencilerin BKİ ile İyilik hâli ölçek puanları arasında pozitif yönlü düşük düzeyde anlamlı ilişki vardir $(r=0,273, p=0,024)$.

\section{TARTIŞMA}

$\mathrm{Bu}$ çalışmanın amacı üniversite öğrencilerinin BKİlerinin iyilik hâli ve tükenmişlik düzeylerine etkisini değerlendirmektir. Çalışmamızda öğrencilerin iyilik hâli düzeyi arttıkça tükenme ve duyarsızlaşma durumları azalmaktadır. Öğrencilerin BKI’leri tükenmişlik durumlarını değiştirmezken, iyilik hâli durumlarını olumlu etkilemektedir.

BKİ'inin yaşam tarzı davranışlarına bağlı olarak değiştiği, yaşam tarzı davranışlarının ise, fiziksel ve ruhsal sağlıkla yakından ilişkili olduğu bilinmektedir $(23,24)$. Öğrenci popülasyonunda sağlıksız beslenme, sigara, alkol kullanımı ve aktivite azlığı gibi belirlenen nedenlerle kronik hastalıkların görülme eğilimi artmaya devam edecek şekilde endişe vericidir. Sağlıksız yaşam tarzının değişmemesi nedeni ile kronik hastalıklara bağlı gelişecek hastalıkların görülme oranının değişmeyeceği vurgulanmıștır (23). Bir çalışmada erkeklerin kızlardan hafta boyunca daha düzenli olarak egzersiz yaptığı ancak erkeklerin daha fazla oranda sigara kullandığı belirlenmiştir. BKİ artışı ile sistolik ve diastolik kan basıncının değiştiği de vurgulanmıştır (24).

Çalışmamızda benzer şekilde öğrencilerin yarıdan fazlasının düzenli beslenme alışkanlığının olmadığı ancak sevindirici olarak çoğunun sigara ve alkol alışkanlığı olmadığı belirlenmiştir. Bu sonuç öğrencilerin çoğunun ekonomik durumlarının orta seviyede olması nedeni ile sigara ya da alkol gibi alışkanlıklara ayrı bir bütçe ayırmadığını ve çalışmaya katılan öğrencilerin daha çok 1.sınıf olması, aile ortamından yeni ayrılmasından kaynaklanabileceği düşünülmektedir.

İnsanlar sağlıklı yaşam seçenekleri ve riskleri hakkında yeterince bilgi sahibi olamadıklarından sağlıklarına zarar verici bir yaşam tarzı sürdürebilmektedirler. Kronik hastalıklar, genellikle yaşamın ilk yıllarında edinilen sağlıksız yaşam tarzından kaynaklanmaktadır. Etnik ve ailesel gelenekler özellikle yeme ve içme alışkanlıkları, bireyin sağlığını geliştirici veya bozucu davranış örüntüleri ya da yaşam tarzı geliştirmesine neden olmaktadır (25).

Üniversite öğrencileri üzerinde yapılan çalışmalarda aşırı kilo ve obezite oranları sırası ile Shahrekord Tip Bilimleri Üniversitesi öğrencilerinde $\% 7,5$ ve $\% 0,5$, Tahran Üniversitesi'nde \%13,5 ve \%3,2, Rafsanjan Tip Bilimleri Üniversitesi'ndeki öğrencilerde $\% 10,7$ ve $\% 1,4$ olarak belirilmiştir $(26,27)$. Türkiye'de bir üniversitede yapılan çalışmada ise, katılımciların \%24,2'sinin fazla kilolu ve \%8,6'sinin obez olduğu sonucuna ulaşılmıştır (28). Suudi Arabistan'da yapılan çalışmada ise, öğrencilerin \% 21,7'si fazla kilolu ve \% 8,4 'si obezdir (29). Amerika'da 14.322 üniversite öğrencisinin yeme davranışlarının incelendiği bir çalışmada, öğren- 
cilerin \%48'inin normal kilolu, \%25,7'sinin fazla kilolu, \%22,9'unun obez olduğu belirlenmiștir (30).

Geçen yıllar içinde genç yetişkinler arasında fazla kilolu ve obez olma oranlarının giderek artması dikkat çekicidir. Çalışmamızda ise aşırı kilo ve obezite oranları sırası ile \%16,6 ve \%3,6 olarak tespit edilmiştir. Çalışmamızda öğrencilerin \%53,1'inin düzenli beslenme alışkanlığının olmaması oldukça önemli bir risktir. Öğrencilerin \%79,9'unun BKİ normal sınırlarda olmasına rağmen çoğunun düzensiz beslenmesi gelecekte endişe verici şekilde aşırı kilo ve obezite oranlarının artacağını düşündürmektedir. Öte yandan bireylerin sağlıklı yaşam biçimi alışkanlıklarını benimsemesi ve sürdürmesi pek çok hastalığ karşı önleyici bir rol oynamaktadır. İyilik hâlinin sağlıklı yaşam biçimi olarak tanımlandığı dikkate alındığında bunu sağlayan davranışların neler olduğu önem kazanmaktadır. Bu davranışlar, yeterli ve dengeli beslenme alışkanlıklarına sahip olma, stresi iyi yönetebilme, düzenli fiziksel etkinlik yapma, spiritüel büyümeyi destekleyici etkinlikler yapma, kişilerarası ilişkileri canlı tutma vb. olarak özetlenmektedir (31). Bireylerin sağlıklı yaşam tarzı davranışları sürdürmeleri onların sağlık seviyelerini koruyan ve iyi olma durumlarını yükselten özelliklerdir (32).

Yapılan bir çalışmada bireylerin iyilik hâlinin yüksek düzeyde olduğu, kadınların erkeklere göre daha yüksek düzeyde iyilik hâline sahip olduğu bulunmuştur (15). Başka bir çalışmada öğrencilerin psikolojik iyilik hallerinin cinsiyete göre, öğrenim gördükleri fakülteye ve alanlarına göre farklılaşmadığı görülmüştür(14). Bazı çalışmalarda ise cinsiyete, okuduğu bölüme ve psikolojik sağlamlığına göre iyilik hâlinin farklılaştığı belirlenmiştir $(33,34)$.Çalışmamızda öğrencilerin okuduğu bölüme göre iyilik hâli ve tükenmişlik durumu değişiklik göstermiştir. Bu durumu öğrencilerin okuduğu bölümler açısından kişisel doyum sağlayamadıkları şeklinde yorumlanabilir.

Obezite ve aşırı kilo da genel popülasyonda tükenmişlikle yüksek düzeyde ilişkili olabilir (35). Yapılan bir çalışmada diyabet hastalarında ve obez olan hastalarda sağlıklı bireylere göre tükenmişlik düzeyi yüksek bulunmuştur (36).Ancak Armutlukuyu'nun çalışmasında obez olanların normal kilolu alanlara göre tükenmişlik düzeyleri düşük bulunmuştur (37). Çalışmamızda ise BKİ ile tükenmişlik arasında ilişki bulunmamıştır. Tükenmişlik durumu öğrencinin okuduğu bölüme göre değişiklik göstermektedir. Beslenme bölümünde okuyan öğrencilerin tükenmişlik düzeyi sağlık kurumları yöneticiliği bölümünde okuyan öğrencilere göre daha yüksektir. Bu sonuç okudukları bölümü seçme nedenleri, mezuniyet sonrası iş bulma ve istihdam durumu gibi faktörlerle ilişkili olabilir. Memiş’in çalışmasında da öğren- cilerin okudukları bölümün, cinsiyetin, sınıfın, ekonomik durumun öğrencilerin tükenmişlik durumunu etkilediği ve sınıf arttıkça öğrencilerin sosyal kaygılarının azaldığı, kız öğrencilerin sosyal anksiyetelerinin daha fazla olduğu belirlenmiştir. Sınıf arttıkça duygusal tükenme ve duyarsızlaşma artmaktadır (38). Çalışmamızda tükenmişlik düzeyi ölçek alt boyutlarında sırasıyla en yüksek duygusal tükenme, duyarsızlaşma ve yetkinlik şeklindedir.

Bu çalışmada üniversite öğrencilerinin iyilik hâli ve tükenmişlik düzeylerinin BKİ açısından değerlendirilmesinin literatüre katkı sağlayacağı düşünülmektedir. Ayrıca çalışma kapsamında öğrencilerin antropometrik ölçümünün yapılması genel sağlık taraması açısından önemlidir. Ancak çalışmanın Afyonkarahisar ilinde ve üniversite öğrencileri kapsamında yapılması araştırmanın sınırlılıkları arasındadir.

Literatürde iyilik hâlini değerlendirmeye yönelik çalışmalar mevcuttur $(13,22,39,40)$. Yapılan çalışmalarda öğrencilerin gelecekle ilgili düşünceleri olumluya doğru gittikçe iyilik hâli puan ortalamalarının da yükseldiği görülmüştür $(13,33)$. Birçok araştırmacı fiziksel olarak aktif olma, sağlıklı ve dengeli beslenmenin sağlık için koruyucu olacağında ortak kanıdadır. Bireylerin sağlığı ve iyilik hâli ile sürdürmekte olduğu yaşam şekli davranışları birbirini etkilemektedir $(31,33,40,42)$. Çalışmamızda öğrencilerin iyilik hâli düzeyi arttıkça yetkinlik durumları artmakta, tükenme ve duyarsızlaşma durumları azalmaktadır. Öğrencilerin BKİleri tükenmişlik durumlarını değiştirmezken, iyilik hâli durumlarını olumlu etkilemektedir.

İyilik hâlinin yüksek olması bireylerin yaşam tarzlarının da daha sağlıklı olduğuna işaret etmektedir. Egzersiz yapma sıklığının artması, alkol kullanma sıklığının azalması, gelecekle ilgili olumlu düşünceler öğrencilerde iyilik hâlini yükselten durumlar olarak belirtilmiştir (13). Çalışmamızda ölçeğin en yüksek alt boyutu yaşamı anlamlandırma ve hedef odaklı olma durumudur. Bu durum öğrencilerin hem bilişsel hem de entelektüel boyutunun yüksek olduğunu göstermiştir. Ancak bilişsel düzeyin artırılması ve kronik hastalıklardan korunmak için sağlıklı beslenmenin ve düzenli fiziksel egzersiz yapılmasının önemli olduğu düşünülmektedir.

Ülkemizde genç nüfus tüm nüfusun \%16,1'ini oluşturmaktadır. Genç populasyonu en fazla etkileyen obezite ve diyabet oranları diğer hastalıklara zemin hazırlamakta, toplumda her geçen gün artış göstermektedir. Ancak bunun yanında değiştirilebilir yaşam tarzı ile obezite ve diyabet görülme oranı azaltılarak daha sağlıklı bir populasyona ulaşılabileceği bilinmektedir. Bu bağlamda üniversite gençliğinin düzenli bir beslenme alışkanlığı kazandırılması 
yönünde kurumsal sorumlulukların da genişletilmesinin faydalı olacağı düşünülmektedir. Buna yönelik gençlik döneminde hazır gıda tüketimi ve kronik hastalıkların hızlı artışı konusunda bilgilendirme eğitimi ve güncel konferans vb. etkinliklere öğrencilerin katılımı sağlanarak farkındalık çalışmaları artırılmalıdır.

\section{KAYNAKLAR}

1. Şanlıer N, Konaklıoğlu E, Güçer E. Gençlerin beslenme bilgi, alışkanlık ve davranışları ile beden kitle indeksleri arasındaki ilişki. Gazi Eğitim Fakültesi Dergisi. 2009;29(2):333-352.

2. Kadıoğlu M, Ergün A. Üniversite öğrencilerinin yeme tutumu, öz-etkililik ve etkileyen faktörler. MUSBED. 2015;5(2):96-104.

3. Arslan SA, Daşkapan A, Çakır B. Üniversite öğrencilerinin beslenme ve fiziksel aktivite alıskanlıklarının belirlenmesi. TAF Preventive Medicine Bulletin. 2016;15(3):171-180.

4. Liu J, Lee B, McLeod DM, Choung H. Framing obesity: effects of obesity labeling and prevalence statistics on public perceptions. Health Education \& Behavior. 2019;46(2):322328.

5. Jesindha B, Rini JS. Epıdemiological study on prevalence of diabetes, hypertension, and effect of obesity on the above parameters. Global Journal For Research Analysis. 2019;8(5):46.

6. Tian S, Liu Y, Feng A, Lou K, Dong H. Metabolically healthy obesity and risk of cardiovascular disease, cancer, and all-cause and cause-specific mortality: A protocol for a systematic review and meta-analysis of prospective studies. BMJ Open. 2019;9:e032742.

7. Tedik SE. Fazla kilo / obezitenin önlenmesinde ve sağlıklı yaşamın desteklenmesinde hemşirenin rolü. Türkiye Diyabet ve Obezite Dergisi. 2017;2:54-62.

8. Censin JC, Peters SAE, Bovijn J, Ferreira T, Pulit SL, Mägi R, et al. Causal relationships between obesity and the leading causes of death in women and men. Plos Genet. 2019;15(10): e1008405.

9. Sağlık Bakanlığı Türkiye Halk Sağlığı Kurumu. Obezitenin Nedenleri (https://hsgm.saglik.gov.tr/tr/obezite/obeziteninnedenleri.html Erişim tarihi: 16.01.20)

10. Genç C, Köse B. Obezite ve dürtüsellik. Başkent Üniversitesi Sağlık Bilimleri Fakültesi Dergisi. 2019;4(2):95-104.

11. World Health Organization (2011). Mental health: A state of wellbeing. (Retrieved from http://www.who.int/ features/ factfiles/mental_health/en/index.html. Erişim tarihi: 11.02.20)

12. Sönmez S, Seyhan GB. Okul öncesi eğitim programının sağlık kavramı açısından incelenmesi. Turkish Online Journal of Qualitative Inquiry (TOJQI). 2016;7(1):146-174.

13. Doğan T. Üniversite öğrencilerinin iyilik halinin "maneviyat" ve "serbest zaman" boyutlarının incelenmesi. Turk Psikolojik Danışma ve Rehberlik Dergisi. 2006;26:1-16.
14. İlğan A, Sevinç ÖS, Niron DG, Kılıç A, Yumuşak A. Lisans öğrencilerinin psikolojik iyilik hallerinin ygs puanları ve çeşitli değişkenler ile ilişkisi. Mersin Üniversitesi Eğitim Fakültesi Dergisi. 2015;11(2):470-486.

15. Uysal H, Oruçoğlu HB. Bireylerin kardiyovasküler sağlık durumlarının ve iyilik hallerinin belirlenmesi. Kardiyovasküler Hemşirelik Dergisi. 2019;10(22):67-77.

16. Lancet T. Physician burnout: A global crisis. Lancet. 2019; 394(10193):93.

17. Kulualp GH, Sarı Ö. Tükenmişlik sendromu: kamu kurulușu çalışanları üzerine bir uygulama. Süleyman Demirel Üniversitesi Sosyal Bilimler Enstitüsü Dergisi. 2019;(35):211230.

18. Schaufeli WB, Leiter MP, Maslach C. Burnout: 35 years of research and practice. Career Development International. 2009;14(3):204-220.

19. Ertürk E, Erdirençelebi M, Şen Ş. Sağlık çalışanlarının tükenmişlik sendromu düzeyleri ile hedonik tüketim davranışları arasındaki ilişki. Selçuk Üniversitesi Sosyal Bilimleri Enstitüsü Dergisi. 2019;(Prof. Dr. Fuat Sezgin Özel Say1s1):141-152.

20. Schaufeli WB, Martinez I, Marques-Pinto A, Salanova M, Bakker A. Burnout and engagement in university students: A cross-national study. Journal of Cross-Cultural Studies. 2002;33:464-481.

21. Çapri B, Gündüz B, Gökçakan Z. Maslach tükenmişlik envanteri-öğrenci formu (MTE-ÖF)'nun türkçe'ye uyarlaması: geçerlik ve güvenirlik çalışması. Çukurova Üniversitesi Eğitim Fakültesi Dergisi. 2011;40(1):134-147.

22. Owen FK, Doğan T, Demirbaş NÇ, Owen DW. İyilik hali yildızı ölçeği'nin geliștirilmesi. Journal of Human Sciences. 2016;13(3):5013-5031.

23. Aceijas C, Waldhäusl S, Lambert N, Cassar S, Corassa RB. Determinants of health-related lifestyles among university students. Perspectives in Public Health. 2017;137(4):227-236.

24. Rafiee E, Khaledi M, Madmoli M, Zafari M, Lotfizadeh M. The correlation between blood pressure and bmi in students of shahrekord university of medical sciences in 2013-14. International Journal of Ayurvedic Medicine. 2019;10(1):113117.

25. Doğan T. Üniversite öğrencilerinin iyilik halinin incelenmesi. Yayınlanmamış Doktora tezi, Hacettepe Üniversitesi, 2004, Ankara.

26. Janssen I, Bacon E, Pickett W. Obesity and its relationship with occupational injury in the canadian work force. Journal of Obesity, 2011:531403.

27. Barzin M, Hosseinpanah F, Arzhan SFA. Trends of obesity and abdominal obesity in Tehranian adults (1999-2008). Pejouhandeh. 2011;16:212-228.

28. Kahraman Ç. Üniversite öğrencilerinde beslenme alışkanlıkları ve obezite riski: Tekirdağ namık kemal üniversitesi örneği. Namık Kemal Üniversitesi Sosyal Bilimler Enstitüsü Sağlık Yönetimi Anabilim Dalı. Yayınlanmamış Yüksek Lisans Tezi 2018, Tekirdăg. 
29. Mehmood Y, Al-Swailmi FK, Al-Enazi SA. Frequency of obesity and comorbidities in medical students. Pakistan Journal of Medical Science. 2016;32(6):1528-1532.

30. Nagata JM, Garber AK, Tabler JL, Murray SB, BibbinsDomingo K. Prevalence and correlates of disordered eating behaviors among young adults with overweight or obesity. Journal of General Internal Medicine. 2018;33(8):1337-1343.

31. Owen FK, Çelik ND. Yaşam boyu sağlıklı yaşam ve iyilik hali. Psikiyatride Güncel Yaklaşımlar. 2018;10(4):440-453.

32. Zaybak A, Fadıloğlu Ç. Üniversite öğrencilerinin sağlığı geliştirme davranışı ve bu davranışı etkileyen etmenlerin belirlenmesi. Ege Üniversitesi Hemşirelik Yüksekokulu Dergisi. 2004;20:71-95.

33. Gürgan U. Üniversite öğrencilerinin yılmazlık ve iyilik halinin bazı değişkenlere göre incelenmesi. E-Journal of New World Sciences Academy. 2014;9:19-35.

34. Owen FK, Çelik ND, Doğan T. Yetişkinlerde iyilik hali. Uluslararası Sosyal Araştırmalar Dergisi. 2017;10(53):600611.

35. Fritschi C, Quinn L. Fatigue in patients with diabetes: A review. J Psychosom Res. 2010;69(1):33-41.

36. Aydın Ö, Göçmen AY, Okyay MY, Çağlayan EK. Diyabetik hastalar ve obezlerde tükenmişlik sendromu ve hematolojik parametreler. Bozok Üniversitesi Tip Dergisi. 2013;3(3):1-5.
37. Armutlukuyu M. Tıp Fakültelerinde çalışan öğretim üyeleri ve araştırma görevlilerinde tükenmişlik düzeylerinin değerlendirilmesi. Selçuk Üniversitesi Tıp Fakültesi. Yayınlanmamış Tıpta Uzmanlık Tezi, Aile Hekimliği Anabilim Dalı 2014, Konya

38. Memiş Ç. Trakya üniversitesi tıp fakültesi öğrencilerinde sosyal anksiyete bozukluğu ve belirtileri ile tükenmişlik düzeylerinin değerlendirilmesi. Trakya Üniversitesi Tip Fakültesi Ruh Sağlığı ve Hastalıkları Anabilim Dalı Uzmanlık Tezi, 2011, Edirne.

39. Diener E, Wirtz D, Tov W, Kim-Prieto C, Choi DW, Oishi S, Biswas-Diener R. New well-being measures: Short scales to assess flourishing and positive and negative feelings. Social Indicators Research. 2010;97(2):143-156.

40. Fidan M, Usta F. İyilik hali ölçeğinin Türkçe formunun güvenirlik ve geçerliğinin incelenmesi. Eğitim ve Öğretim Araştırmaları Dergisi. 2013;2(3):265-269.

41. Sisson SB, Smith CL, Cheney M. Bigimpact on smallchildren: child-care providers' perceptions of their role in early childhood healthy lifestyle behaviours. Child Care Pract. 2017;23:162-180.

42. Song M, Giovannucci E. Preventable incidence and mortality of carcinoma associated with lifestyle factors among white adults in the United States. JAMA Oncol. 2016;2:1154-1161. 